TP Periodica Polytechnica Chemical Engineering

59(3), pp. 206-208, 2015

DOI: $10.3311 /$ PPch.7583

Creative Commons Attribution (i)

RESEARCH ARTICLE

\section{Vinaigrette Production by Membrane Emulsification: Process Optimization and Product Development}

\author{
Krisztina Albert ${ }^{1 *}$, András Koris ${ }^{1}$, Shabbir Ahammed ${ }^{1}$, \\ Igor Gáspár ${ }^{1}$, Gyula Vatai ${ }^{1}$ \\ Received 06 June 2014; accepted after revision 25 November 2014
}

\begin{abstract}
In present work primarily achievement in energy efficient food production were targeted. Over the last 20 years, there has been a growing interest in a technique for making emulsions known as "membrane emulsification" which allows the production of emulsion droplets under controlled conditions with a narrow size distribution. Vinaigrette is a mixture of oil and vinegar. In the present work vinaigrette was prepared in two ways. The first one was prepared by hand in the traditional way. The second sample was pr epared by membrane technology. After preparation of vinaigrette, the panel test is carried out by trained panelist in order to know the quality and customer preference. After series of experiments and data analysis it can be concluded that cross-flow ME is suitable for green production of $W / O$ emulsions like vinaigrette, and the technology we used looks suitable for industrial applications.
\end{abstract}

\section{Keywords}

Membrane emulsification, vinaigrette, oil-in-water emulsion, product development

${ }^{1}$ Corvinus University of Budapest,

Ménesi út 44., H-1118 Budapest, Hungary

*Corresponding author, e-mail: krisztina.albert1986@gmail.com

\section{Introduction}

Emulsion preparation is a common and significant industrial and household process. Therefore methods to improve this process in order to prepare a better product and/or reduce the energy costs are of the utmost importance. These systems are commonly encountered in key processes, e.g. in the pharmaceutical and food industry as well as in cosmetic products. Both the average droplet size and size distribution are very important properties, since they determine the emulsion stability and its properties for the intended uses. Water in oil emulsion plays an important role to produce different kinds of food product. Our aim is to prepare this type of emulsion by using relatively new technology called cross-flow membrane emulsification. The main objective of this research study is to investigate the optimum operating conditions for emulsification such as driving force, shear stress and membrane pore diameter, significantly contributing to prepare homogenize emulsion.

Over the last 20 years, there has been a growing interest in a technique for making emulsions known as "membrane emulsification" which allows the production of emulsion droplets under controlled conditions with a narrow size distribution [1]. It is applicable to $\mathrm{O} / \mathrm{W}, \mathrm{W} / \mathrm{O}$ and multiple emulsions [2].

In case of cross-flow membrane emulsification the disperse phase is pressed through the membrane pores under pressure, and forms droplets at the pore openings in the membrane surface, which are detached by the cross- flowing continuous phase [3]. The membrane emulsification process is generally carried out in cross-flow (continuous or batch) mode or in a stirred cell (batch) [4]. Both the size and the size distribution of droplets may be carefully controlled choosing suitable membranes and focusing on some fundamental process parameters. Successful emulsification can be carried out with much less consumption of emulsifier and energy. There are different types of membranes which can be used for preparation of emulsion. In case of cross-flow membrane emulsification the application of static mixing is considerable to reduce the energy consumption of the operation in large numbers [5]. According to literature review, discussion of salad dressing or vinaigrette production by ME was not found. 
Vinaigrette is a mixture of oil and vinegar (plus salt, pepper and other seasonings). The word is from the French "vinaigre", which means vinegar. The ratio of oil and vinegar is about $2: 1$ or $3: 1$ and vinaigrette is usually manually produced. It is called a temporary emulsion because the oil and vinegar begin to separate as soon as the mixing is stopped. Any kind of oils labelled ,vegetable oil” or ,salad oil” and also light, neutralflavoured oil like sunflower, canola or soybean oil can be used to make basic vinaigrette. One of the most common variations is to substitute olive oil for salad oil.

\section{Materials and methods}

\subsection{Membrane emulsification process optimisation}

In the optimization experiments commercial grade sunflower oil was used. The density of the oil was $922 \mathrm{~kg} / \mathrm{m}^{3}$ and viscosity was $\eta=69 \mathrm{mPas}$. Ceramic tube membranes ( $\alpha$ alumina) with $1.4 \mu \mathrm{m}$ mean pore size and with $50 \mathrm{~cm}^{2}$ active membrane surface were investigated. In order to increase energy efficiency spiral-ribbon static mixer was installed in the lumen side of the membrane. The length of one complete turn in the spiral was 24 $\mathrm{mm}$, the width was $6 \mathrm{~mm}$ and the thickness was $1 \mathrm{~mm}$.

The $3^{\mathrm{p}}$ experimental design was evaluated in 2 ways, without static mixer and membrane equipped with helix shaped static mixer. The two sets of experiment were carried out with in the similar operating conditions. Without static mixer the axial cross-flow velocity in the tube membranes was varied in the range from $0.58 \mathrm{~m} / \mathrm{s}$ to $1.15 \mathrm{~m} / \mathrm{s}$ when the recirculated flowrate (RFR) was between $230 \mathrm{~L} / \mathrm{hr}$ and $460 \mathrm{~L} / \mathrm{hr}$. In case of using the static mixer, in order to keep the same shear stress which was obtained by without reducer, the RFR was set on the pump at $20 \mathrm{~L} / \mathrm{hr}$ and $40 \mathrm{~L} / \mathrm{hr}$. With these experimental settings, the value of the shear -stress was the same in each case, namely 9.5 $\mathrm{Pa}$ and $19 \mathrm{~Pa}$. The pressure of dispersed phase was assured by air compressor. It was injected from the shell side of the membrane. The oil was re-circulated on the lumen side of the membrane by a common peristaltic pump.

The experimental set-up used for the experiments is shown in Fig. 1. It included a pump (4) which was connected to the

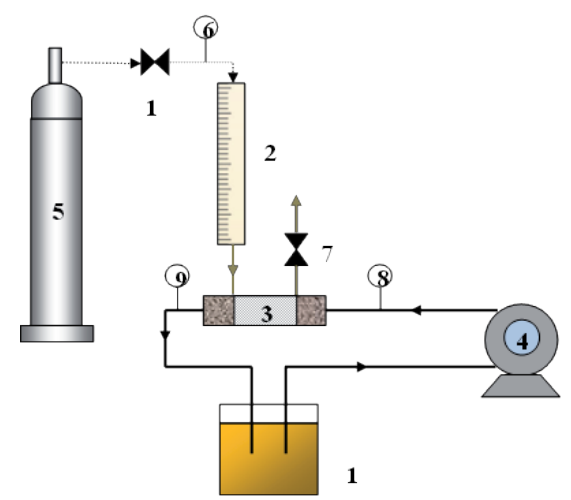

Fig. 1 Experimental set-up for the cross-flow membrane emulsification process

continuous phase tank (1) and the membrane module (3). Two manometers (8-9), one placed before membrane and the other placed after the membrane, were used to measure the pressure drop through the membrane. A rotameter, placed at the exit of the membrane, allowed to measure the flow rate of oil. The bottom of the disperse phase tank (2) was connected to the membrane and the top was connected with the compressor (5) to ensure the pressure of water. There was another manometer (6), between the compressor and dispersed phase tank, which was indicating the pressure of the disperse phase tank.

Response surface methodology (RSM) is a collection of mathematical and statistical techniques and it is a good tool for studying the effect of several factors at different levels and their influence on each other. To describe the effect of the two operating parameters, driving force (DF) and shear-stress $(\tau)$ on disperse phase flux (DPF), droplet size (or diameter) and span, a model based on $3^{\mathrm{p}}$ type full factorial experimental design was set up. This is a non-linear function relationship where a factor is tested on three levels (minimum, middle point and maximum). The general polynomic regressive function for this model is shown in Eq. (1).

$$
\mathrm{Y}=\mathrm{b}_{0}+\sum \mathrm{b}_{\mathrm{L}} \mathrm{X}_{\mathrm{L}}+\sum \mathrm{b}_{0} \mathrm{X}_{0}^{2}+\sum \mathrm{b}_{12} \mathrm{X}_{1} \mathrm{X}_{2},
$$

where $\mathrm{Y}$ is the dependent variable, $\mathrm{b}_{\mathrm{n}}$ symbolizes the constants, $X_{n}$ stands for the independent variables. The experimental design table and responses can be seen in Fig. 2.

\begin{tabular}{|c|c|c|c|c|c|}
\hline \multirow[b]{2}{*}{$\begin{array}{l}\text { Standard } \\
\text { Run }\end{array}$} & \multicolumn{5}{|c|}{$\begin{array}{l}3^{n *}(2-0) \text { full factorial design, } 1 \text { block, } 9 \text { runs (Spreadsheet2) } \\
+3 \text { center points per block }\end{array}$} \\
\hline & Driving force & $\begin{array}{c}\text { Shear stress } \\
(\mathrm{Pa})\end{array}$ & $\begin{array}{c}\begin{array}{c}\text { Flux } \\
\left(\mathrm{ml} / \mathrm{m}^{2} / \mathrm{s}\right)\end{array} \\
\end{array}$ & $\begin{array}{l}\text { Diameter } \\
(\mu \mathrm{m})\end{array}$ & Span \\
\hline 1 & 4 & 0.0 & 85.11 & 13.78 & 1.4 \\
\hline 2 & 4 & 9.5 & 84.21 & 12.66 & 1.47 \\
\hline 3 & 4 & 19.0 & 81.64 & 9.94 & 1.13 \\
\hline 4 & 7 & 0.0 & 110.82 & 13.67 & 1.26 \\
\hline 5 & 7 & 9.5 & 108.18 & 10.76 & 1.49 \\
\hline 6 & 7 & 19.0 & 105.86 & 8.67 & 1.46 \\
\hline 7 & 10 & 0.0 & 137.04 & 15.03 & 1.52 \\
\hline 8 & 10 & 9.5 & 130.3 & 10.74 & 1.31 \\
\hline 9 & 10 & 19.0 & 129.45 & 13.26 & 1.25 \\
\hline 10 & 7 & 9.5 & 107.82 & 9.81 & 1.57 \\
\hline 11 & 7 & 9.5 & 109.01 & 9.26 & 2.29 \\
\hline 12 & 7 & 9.5 & 109.29 & 11.21 & 1.36 \\
\hline
\end{tabular}

\begin{tabular}{|c|c|c|c|c|c|}
\hline \multirow[b]{2}{*}{$\begin{array}{l}\text { Standard } \\
\text { Run }\end{array}$} & \multicolumn{5}{|c|}{$\begin{array}{l}3^{* *}(2-0) \text { full factorial design, } 1 \text { block, } 9 \text { runs (Spreadsheet2) } \\
+3 \text { center points per block }\end{array}$} \\
\hline & Driving force & $\begin{array}{c}\text { Shear stress } \\
(\mathrm{Pa})\end{array}$ & $\begin{array}{c}\text { Flux } \\
\left(\mathrm{ml} / \mathrm{m}^{2} / \mathrm{s}\right.\end{array}$ & $\begin{array}{l}\text { Diameter } \\
(\mu \mathrm{m})\end{array}$ & Span \\
\hline 1 & 4 & 0.0 & 88.11 & 9.31 & 1.19 \\
\hline 2 & 4 & 9.5 & 89.09 & 9.26 & 2.04 \\
\hline 3 & 4 & 19.0 & 84.92 & 12.14 & 1.84 \\
\hline 4 & 7 & 0.0 & 116.99 & 8.53 & 1.66 \\
\hline 5 & 7 & 9.5 & 108.7 & 11.35 & 1.33 \\
\hline 6 & 7 & 19.0 & 107.55 & 15.24 & 0.73 \\
\hline 7 & 10 & 0.0 & 147.06 & 9.17 & 1.41 \\
\hline 8 & 10 & 9.5 & 139.38 & 11.06 & 1.59 \\
\hline 9 & 10 & 19.0 & 137.01 & 9.02 & 1.88 \\
\hline 10 & 7 & 9.5 & 113.98 & 10.51 & 1.92 \\
\hline 11 & 7 & 9.5 & 113 & 11.23 & 1.25 \\
\hline 12 & 7 & 9.5 & 115.28 & 8.52 & 1.62 \\
\hline
\end{tabular}

Fig. 2 The $3 p$ full factorial design of independent variables (DF and $\tau$ ) and dependent variables (Flux, Diameter, Span) for $1.4 \mu$ m, without and using static mixer 

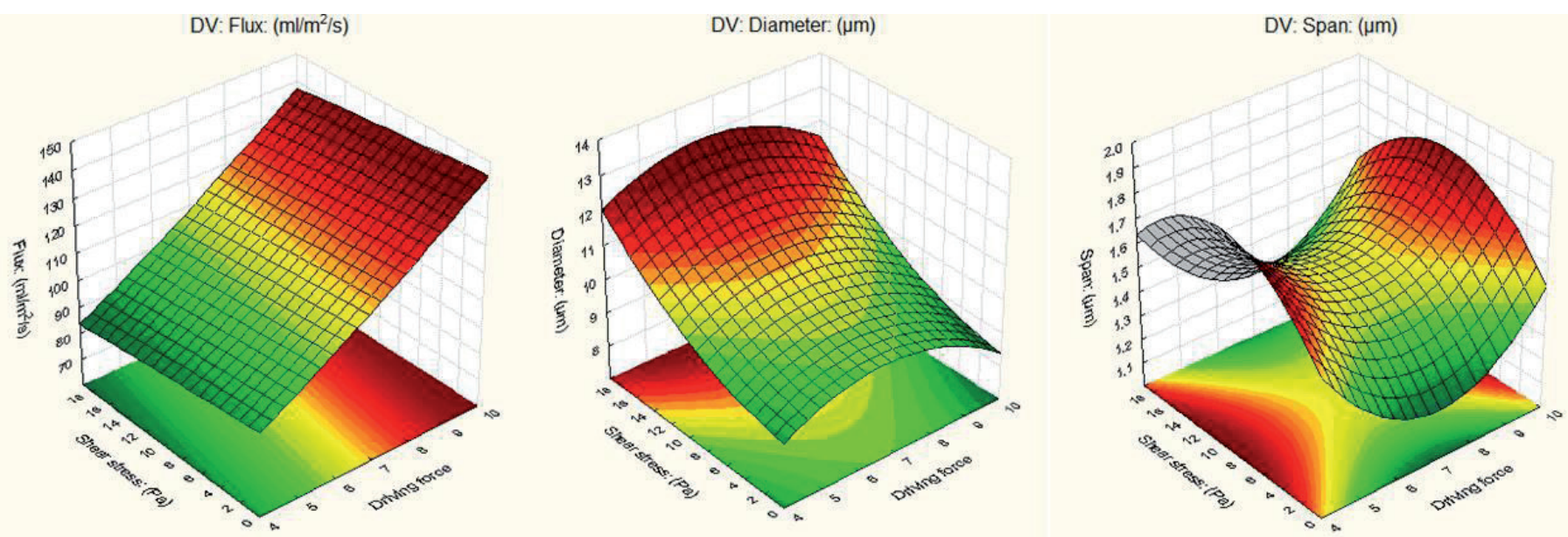

Fig. 3 Flux, Droplet size and Span vs. shear-stress and driving force - the model surfaces

Based on the experimental plan the most effective operating conditions of emulsion production were observed: $\tau=9.5$ $\mathrm{Pa}(\mathrm{RFR}=40 \mathrm{~L} / \mathrm{hr}), \mathrm{DF}=7$ (the pressure of the dispersed phase $=2.3$ bars) and it is also recommended the use of static mixer because of its positive impact.

\subsection{Preparation of Vinaigrette by ME}

Commercial white wine vinegar from white wine $6 \%$ was purchased from local market. The $1.5 \mathrm{~m} / \mathrm{m} \%$ water solution was formed as dispersed phase with $15 \mathrm{ml}$ surfactant (Tween 80) and $985 \mathrm{ml}$ vinegar. The "Floriol Mediterrán" oil (sunflower oil $90 \%$ and olive oil 10\% - from Bunge Zrt.) were purchased from local market as well. The flow rate of oil was set at $40 \mathrm{~L} / \mathrm{hr}$ and the pressure of vinegar at 2.3 bars.

\section{Results summary}

The main results of the $3 p$ experiments carried out with the membrane with pore size of $1.4 \mu \mathrm{m}$ it can be concluded that:

1. Basic, non-linear working formulas were worked out for vinaigrette production;

2. Optimal operating conditions were found for vinaigrette production by ME.

3. Result of pumping power requirement calculations allows concluding that:

In general $92 \%$ less energy required for recirculation of the continuous phase and emulsion with static mixer (compared to the case when no static mixer was used).

4. Result of sensory analyses of handmade and membrane produced vinaigrettes:

No significant difference between handmade and ME product, however panelists gave little bit higher points to $\mathrm{ME}$ vinaigrette.

After series of experiments and data analysis it can be concluded that cross-flow ME is suitable for green production of $\mathrm{W} / \mathrm{O}$ emulsions like vinaigrette, and the technology we used looks suitable for industrial applications. Based on experimental data mathematical models were established and process optimization was carried in order out to determine crucial operating parameters. It was concluded as well that applying given static mixer inside a tubular ceramic membrane can make the ME process even more energy efficient without any negative effects in terms of productivity and emulsion quality.

\section{Acknowledgements}

The authors would like to express their acknowledgement to the Hungarian National Scientific Foundation TÉT 10-12011-0072, OTKA K68596 and TÁMOP-4.2.1/B-09/1/KMR2010-0005 and for MEMFIDA2 project (EUREKA_HU_081-2010-0010) for the support.

\section{References}

[1] Charcosset, C., Limayem, I., Fessi, H. "The membrane emulsification process - a review." Journal of Chemical Technology and Biotechnology. 79 (3). pp. 209-218. 2004. DOI: 10.1002/jctb.969

[2] Vladisavljevic, G. T., Williams, R. A. "Recent developments in manufacturing emulsions and particulate products using membranes." Advances in Colloid and Interface Science. 113 (1). pp. 1-20. 2005. DOI: 10.1016/j.cis.2004.10.002

[3] Vladisavljevic, G. T., Brösel, S., Schubert, H. "Preparation of Waterin-Oil Emulsions Using Microporous Polypropylene Hollow Fibres: Conditions for Producing Small Uniform Droplets." Chemical Papers. 54 (6a). pp. 383-388. 2000.

[4] De Luca, G., Dimaio, F. P., Di Renzo, A., Drioli, E. "Droplet detachment in cross-flow membrane emulsification: Comparison among torque- and force-based models." Chemical Engineering and Processing: Process Intensification. 47 (7). pp. 1150-1158. 2008.

DOI: 10.1016/j.cep.2007.03.010

[5] Koris, A., Piacentini, E., Vatai, G., Bekassy-Molnar, E., Drioli, E., Giorno, L. "Investigation on the effects of a mechanical shear-stress modification method during cross-flow membrane emulsification." Journal of Membrane Science. 371 (1-2). pp. 28-36. 2011. DOI: 10.1016/j.memsci.2011.01.005 